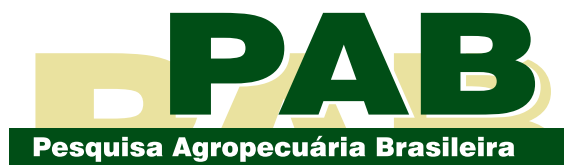

ISSN 1678-3921

Journal homepage: www.embrapa.br/pab

For manuscript submission and journal contents, access: www.scielo.br/pab
Thematic Issue - Regional Agrominerals/ Original Article

\section{Weathering features of a remineralizer in soil under different land uses}

\begin{abstract}
The objective of this work was to analyze the mineralogical, morphological, and compositional modifications resulting from the weathering of diabase grains buried into soil under different land uses for up to 378 days. Samples of comminuted diabase were put into polyester bags and buried into soil under corn crop, elephant grass, and woods, being unburied and evaluated after four time periods. The samples of the remineralizer (RM) were analyzed by X-ray diffractometry, total chemical analysis, scanning electron microscopy, and $\mathrm{Al}\left(\mathrm{Al}_{\mathrm{d}}\right.$ and $\left.\mathrm{Al}_{\mathrm{o}}\right)$ and $\mathrm{Fe}\left(\mathrm{Fe}_{\mathrm{d}}\right.$ and $\left.\mathrm{Fe}_{\mathrm{o}}\right)$ contents extracted by sodium dithionite-citrate-bicarbonate (DCB) and ammonium oxalate (AAO) solutions. Plagioclases and pyroxenes were the most weathered minerals in all three land uses and showed the same pattern of elemental gains and losses. The characterization of Fe and $\mathrm{Al}$ solubility in $\mathrm{DCB}$ and $\mathrm{AAO}$ showed that the greatest change in these elements was from the lithogenic and crystalline to the pedogenic and amorphous phase, when compared with their total content. Plagioclases and pyroxenes were the most weathered minerals, and $\mathrm{Fe}$ and $\mathrm{Al}$ show a great transfer from the crystalline to the amorphous phase, with values up to 26 and 175, respectively, for the ratios between bags with $\mathrm{RM} / \mathrm{Fe}_{0}$ and $\mathrm{RM}$-control and bags with $\mathrm{RM} / \mathrm{Al}_{0}$ and $\mathrm{RM}$-control.
\end{abstract}

Index terms: enhanced weathering, mineral dissolution, rock powder.

\section{Características de intemperismo de um remineralizador em solo sob diferentes usos da terra}

Resumo - O objetivo deste trabalho foi analisar as modificações mineralógicas, morfológicas e composicionais resultantes do intemperismo de grãos de diabásio enterrados em solo sob diferentes usos da terra por até 378 dias. Amostras de diabásio cominuído foram colocadas em sacos de poliéster e enterradas em solo sob cultivo de milho, capim-elefante e floresta, tendo sido desenterradas e avaliadas após quatro períodos. As amostras do remineralizador (RM) foram analisadas por difratometria de raios $\mathrm{X}$, análise química total, microscopia eletrônica de varredura, e teores de $\mathrm{Al}\left(\mathrm{Al}_{\mathrm{d}}\right.$ e $\left.\mathrm{Al}_{\mathrm{o}}\right)$ e $\mathrm{Fe}\left(\mathrm{Fe}_{\mathrm{d}}\right.$ e $\left.\mathrm{Fe}_{\mathrm{o}}\right)$ extraídos com soluções de ditionito-citrato-bicarbonato (DCB) e amônio oxalato (AAO). Os plagioclásios e os piroxênios intemperizaram mais rápido nos três tipos de uso da terra, e mostraram o mesmo padrão de ganhos e perdas no balanço de massa de elementos. A caracterização das formas de $\mathrm{Fe}$ e Al em DCB e AAO mostrou que a maior mudança destes elementos foi da fase litogênica e cristalina para a secundária e amorfa, em comparação aos seus teores totais. Os plagioclásios e os piroxênios foram os minerais mais alterados, e $\mathrm{Fe}$ e $\mathrm{Al}$ apresentam grande transferência entre a fase cristalina e amorfa, com valores de até 26 e 175, respectivamente, para as razões entre sacos com $\mathrm{RM} / \mathrm{Fe}_{\mathrm{o}}$ e RM-controle e sacos com $\mathrm{RM} / \mathrm{Al}_{0}$ e $\mathrm{RM}$-controle.

Termos para indexação: intemperismo acelerado, dissolução mineral, pó de rocha. 


\section{Introduction}

Remineralization, the application of powdered rocks into soils, is an agricultural practice to improve edaphic properties and increase biomass productivity (Harley \& Gilkes, 2000; Leonardos et al., 2000; Van Straaten, 2006; Manning, 2010; Silva et al., 2017). It is also a low-cost technology to sequester atmospheric carbon through enhanced weathering and, potentially, lead to carbon mineralization (Manning et al., 2013). The effect of remineralizers (RMs) varies according to several factors, but, ultimately, it is related to the dissolution rate of their minerals (Manning, 2010; Ramos et al., 2015).

Mineral dissolution is a complex phenomenon. Its characterization by standard chemical parameters, such as thermodynamic stability constants and dissolution rates, is determined in laboratory conditions (Garrels \& Christ, 1965; Palandri \& Kharaka, 2004), which is very useful as a starting point, but may deviate from the dissolution rate in field conditions by a factor as great as $10^{2}$ (White \& Brantley, 2003; Yokoyama \& Matsukura, 2006; Ganor et al., 2007). This is so because variables as the mineral:solution ratio, bioweathering, and seasonal variations in moisture and temperature, among others, greatly diverge from those in laboratory conditions (Benedetti et al., 1994; Yokoyama \& Matsukura, 2006; Ganor et al., 2007). Therefore, to properly evaluate and manage the use of RMs in soils, the dissolution of these rocks in field conditions must be well understood and parametrized.

Daval et al. (2018), when analyzing feldspar grains buried into soil for 4 years and comparing the results with those found for minerals weathered under controlled conditions in a laboratory, reported a smaller dissolution rate in the field, which was attributed to the formation of amorphous silica surface layers. Despite this interesting result, the authors did not detail the release of elements from the feldspar nor the formation of secondary phases, possibly because their work was carried out with a single mineral. Gill (2014) also concluded that feldspars of the plagioclase group and pyroxenes are the major minerals in basalts and diabases, and that their dissolution in soil increases $\mathrm{pH}$ and cation exchange capacity, but decreases exchangeable Al, depending on the applied rate and particle size (Anda et al., 2015).

Grains of the diabase RM are basic rocks rich in plagioclases and pyroxenes, minerals that weather fast when compared with other ones such K-feldspars and muscovite (White et al., 1990). In Brazil, those grains are abundant in the Paraná basin, being a potential source of silicon, iron, aluminum, calcium, magnesium, and potassium, particularly in the western region of the state of São Paulo.

The objective of this work was to analyze the mineralogical, morphological, and compositional modifications resulting from the weathering of diabase grains buried into soil under different land uses for up to 378 days.

\section{Materials and Methods}

The used RM is a diabase mined from the Limeira sill, located in the state of São Paulo, Brazil (22³6'31.2"S, $\left.47^{\circ} 21^{\prime} 45.7^{\prime \prime} \mathrm{W}\right)$. The most abundant minerals found were plagioclases and pyroxenes (Figure 1) as expected (Gill, 2014). Faria (2008) describes the Na-Ca solid solution in these plagioclases as $\mathrm{An}_{19}$ at the edges and $\mathrm{An}_{40}$ into the core, i.e., as more sodic and more calcic, respectively. Other minerals - ilmenite, magnetite, k-feldspar, and apatite - were also identified, but in smaller amounts.

For the experiment, polyester bags of $0.15 \times 0.15 \mathrm{~m}$ were made using a 200 mesh cloth and then filled with $300 \mathrm{~g}$ RM. The particle-size distribution of the RM was: $30 \mathrm{~g} \mathrm{~kg}^{-1}$ greater than $2.00 \mathrm{~mm}, 258 \mathrm{~g} \mathrm{~kg}^{-1}$ from 2.00 to $1.00 \mathrm{~mm}, 270 \mathrm{~g} \mathrm{~kg}^{-1}$ from 1.00 to $0.50 \mathrm{~mm}, 143$ $\mathrm{g} \mathrm{kg}^{-1}$ from 0.50 to $0.25 \mathrm{~mm}, 166 \mathrm{~g} \mathrm{~kg}^{-1}$ from 0.25 to $0.125 \mathrm{~mm}, 77 \mathrm{~g} \mathrm{~kg}^{-1}$ from 0.053 to $0.002 \mathrm{~mm}$, and $56 \mathrm{~g} \mathrm{~kg}^{-1}$ smaller than 0.002 .

In January 30, 2014, the bags were buried in a farm in the municipality of Pirassununga, in the state of São Paulo (21 $\left.{ }^{\circ} 58^{\prime} 52.32^{\prime \prime} \mathrm{S}, 47^{\circ} 22^{\prime} 44.27^{\prime \prime} \mathrm{W}\right)$. The climate of the region is tropical seasonal, of the Cwa type, with dry winters from June to August and hot and rainy summers from October to March (Alvares et al., 2013). The annual rainfall is $1,410 \mathrm{~mm}$, and the average annual temperature is $22^{\circ} \mathrm{C}$, with a maximum and a minimum average of 30.8 and $10.6^{\circ} \mathrm{C}$, respectively. Data were obtained from the weather station at the campus of Universidade de São Paulo, also located in the municipality of Pirassununga, in the state of São Paulo.

The experimental areas had the same soil type, classified as a Latossolo Vermelho ácrico típico according to the Brazilian system of soil classification (Santos et al., 2018a), which is equivalent to an Anionic Acrudox (Soil Survey Staff, 2014). However, the areas had three contiguous land uses, less than $1,000 \mathrm{~m}$

Pesq. agropec. bras., Brasília, v.56, e01442, 2021

DOI: 10.1590/S1678-3921.pab2021.v56.01442 
apart: corn (Zea mays L.) fields cultivated under a no-tillage system since 2009 and before that with passion fruit (Passiflora edulis Sims); elephant grass (Pennisetum purpureum Schumach), cultivated as a protective barrier for the field for at least 10 years; and a conservation area, with a forest fragment (woods). In each land use, four bags were buried horizontally, at $0.10 \mathrm{~m}$ depth, totaling $12 \mathrm{bags}$, with the greater axis of the bag parallel to the soil surface.

In the corn field, the bags with the RM (RM-corn) were buried approximately $1.0 \mathrm{~m}$ apart from each other and $0.10 \mathrm{~m}$ from the corn stalks, being unburied 59,86 ,
119, and 154 days later. In the elephant grass site, the bags with the RM (RM-grass) were buried at about 0.10 $\mathrm{m}$ from the tussocks and $2.0 \mathrm{~m}$ apart from each other. In the woods site, the distribution of the bags with the RM (RM-woods) was random, depending on the distribution and location of the tree trunks, ensuring equidistance from the trees around each bag. In both the grass and woods areas, the bags were unburied after $86,182,274$, and 378 days, differing from the unburying times for corn due to the crop's cycle.

Soil samples were collected in each area, at $0.0-0.2$ $\mathrm{m}$ depth, to characterize soil fertility (Table 1) using

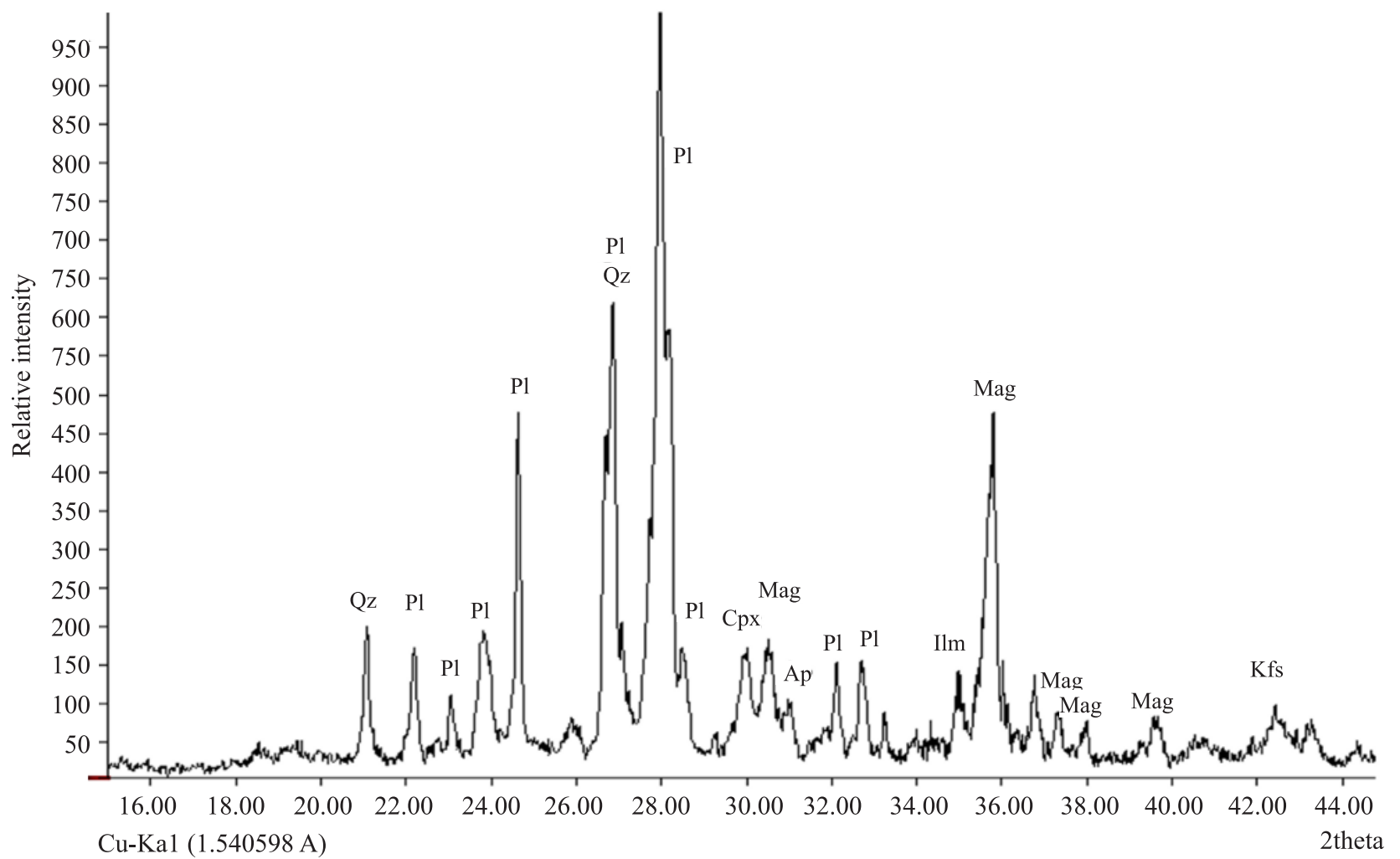

Figure 1. X-ray diffraction patterns of the remineralizer used as the control. Qz, quartz; Pl, plagioclase; $\mathrm{Cpx}$, clinopyroxene; Mag, magnetite; Ap, apatite; Ilm, ilmenite; and Kfs, K-feldspar.

Table 1. Chemical attributes of soil samples collected at 0.0-0.2 $\mathrm{m}$ depth from the experimental areas under corn (Zea mays) crop, elephant grass (Pennisetum purpureum), and woods.

\begin{tabular}{|c|c|c|c|c|c|c|c|c|c|c|c|c|c|}
\hline \multirow[t]{2}{*}{ Land use } & \multirow{2}{*}{$\mathrm{pH}_{\text {water }}$} & $\mathrm{Ca}$ & $\mathrm{Mg}$ & $\mathrm{K}$ & $\mathrm{Al}$ & $\mathrm{H}+\mathrm{Al}$ & $\mathrm{SB}^{(1)}$ & $\mathrm{CTC}^{(2)}$ & $\mathrm{P}$ & $\mathrm{Si}$ & $\mathrm{Fe}$ & $\mathrm{Fe}_{\mathrm{d}}^{(3)}$ & $\mathrm{Fe}_{0}^{(4)}$ \\
\hline & & \multicolumn{7}{|c|}{ - } & \multicolumn{3}{|c|}{-------(mg dm³)------- } & \multicolumn{2}{|c|}{----( $\left(\mathrm{g} \mathrm{kg}^{-1}\right)----$} \\
\hline Corn & 4.8 & 14 & 6 & 3.2 & 0 & 31 & 23.4 & 54.1 & 92 & 12.0 & 33 & 18.9 & 0.5 \\
\hline Grass & 4.2 & 7 & 3 & 1.2 & 1 & 64 & 10.8 & 75.2 & 26 & 8.0 & 37 & 15.8 & 0.3 \\
\hline Woods & 3.9 & 10 & 5 & 1.6 & 4 & 31 & 16.4 & 47.1 & 11 & 7.8 & 109 & 24.9 & 0.6 \\
\hline
\end{tabular}

${ }^{(1)}$ Sum of bases $(\mathrm{Ca}+\mathrm{Mg}+\mathrm{K}) \cdot{ }^{(2)}$ Cation exchange capacity (sum of bases $\left.+\mathrm{H}+\mathrm{Al}\right) \cdot{ }^{\left({ }^{(3)} \text { Iron determined in dithionite-citrate-bicarbonate solution. }{ }^{(4)} \text { Iron }\right.}$ determined in oxalate ammonium acid solution. 
the standard methods of the state of São Paulo (Raij et al., 2001). In both the unburied samples and in the pristine RM (RM-control), pedogenic iron oxides and amorphous metal oxides were solubilized, respectively, in sodium-dithionite-citrate-bicarbonate (DCB) (Mehra \& Jackson, 1958) and in acid ammonium oxalate (AAO) (McKeague, 1978) solutions; the Fe and $\mathrm{Al}$ in the extracts were measured by atomic absorption spectroscopy.

Aliquots of $5 \mathrm{~g}$ from the last unburied bags - at 154 days for the corn site and 378 days for the grass and woods sites - were dry-sieved into: coarse sand (from 1.0 to $0.5 \mathrm{~mm}$ ), fine sand (from 0.25 to $0.125 \mathrm{~mm}$ ), and silt (smaller than $0.05 \mathrm{~mm}$ ), ground until passing through a 60 mesh sieve, then powder mounted and irradiated into the Miniflex II benchtop X-ray diffractometer (XRD, Rigaku Corporation, Tokyo, Japan), with a $\mathrm{CuK} \alpha$ radiation of $0.154056 \mathrm{~nm}$, operated at $30 \mathrm{kV}$ and $15 \mathrm{~mA}$, with a graphite monochromator and $\mathrm{Ni}$ filter. The angular range was 3 to $60^{\circ} 2 \theta$, at $0.02^{\circ} 2 \theta$ step, and $1 \mathrm{~s}$ per step. The XRD patterns were interpreted using the Match! 2.1 software (Crystal Impact, Bonn, Germany).

Total chemical composition was determined only for the longest buried RM and the RM-control, comprising $\mathrm{Al}_{2} \mathrm{O}_{3}, \mathrm{BaO}, \mathrm{CaO}, \mathrm{Cr}_{2} \mathrm{O}_{3}, \mathrm{Fe}_{2} \mathrm{O}_{3}, \mathrm{MgO}$, $\mathrm{MnO}, \mathrm{P}_{2} \mathrm{O}_{5}, \mathrm{~K}_{2} \mathrm{O}, \mathrm{SiO}_{2}, \mathrm{Na}_{2} \mathrm{O}, \mathrm{SrO}$, and $\mathrm{TiO}_{2}$. Aliquots were fused in $\mathrm{LiBO}_{2} / \mathrm{Li}_{2} \mathrm{~B}_{4} \mathrm{O}_{7}$, at $1,000^{\circ} \mathrm{C}$, cooled, and then dissolved in a solution of $4 \%$ nitric acid + $2 \%$ hydrochloric acid. The extract was analyzed by atomic emission spectrometry using inductively coupled plasma (ICP-AES); solution readings were sent to a commercial laboratory, which is why the used equipment has not been disclosed.

Based on the obtained results, the elemental mass balance (EMB) was calculated with the equation:

$\mathrm{EMB}=[(\mathrm{RM}$-corn or RM-grass or RM-woods $)$ (RM-control) / (RM-control)] x 100

Negative values imply loss of elements in the weathered RM, and positive values imply accumulation.

The RM samples were also fixed on an adhesive carbon metallic support coated with gold film and observed under the LEO 435 VP scanning electron microscope (Carl Zeiss Industrielle Messtechnik $\mathrm{GmbH}$, Oberkochen, Germany), in order to determine the fine and coarse sand fractions. The grains were not subjected to cleaning procedures, so that weathering features and biological attachments were preserved on grain surface.

\section{Results and Discussion}

The evaluated $\mathrm{RM}$ was composed by $52.10 \% \mathrm{SiO}_{2}$, $14.45 \% \mathrm{Fe}_{2} \mathrm{O}_{3}, 11.90 \% \mathrm{Al}_{2} \mathrm{O}_{3}, 6.94 \% \mathrm{CaO}, 3.45 \% \mathrm{MgO}$, $3.27 \% \mathrm{TiO}_{2}, 3.06 \% \mathrm{Na}_{2} \mathrm{O}, 1.59 \% \mathrm{~K}_{2} \mathrm{O}, 0.24 \% \mathrm{MnO}$, and $0.75 \% \mathrm{P}_{2} \mathrm{O}_{5}$, as expected for a basic igneous rock (Gill, 2014).

Regarding grain morphology, plain surfaces and strait edges, associated with the cleavage of minerals, were frequently observed in the fine and coarse sand fractions of the RM-control (Figure $2 \mathrm{~A}$ and $\mathrm{B}$ ), as well as occasional features of mechanical stress resulting from the comminution process (Figure $2 \mathrm{C}$ and D). In general, etch pits and corroded depressions were identified in the buried grains (Figure $2 \mathrm{E}$ and F), which are associated with the initial stages of weathering (Heindel et al., 2018). Filamentous material resembling fine roots or fungal hyphae were also frequent (Figure $2 \mathrm{D}$ and F). During unburying, it was common to observe roots wrapping around the bags, particularly in the grass land use. Biological corrosion was inferred from some images (Figure $2 \mathrm{~F}$ ), and similar structures were found in gneiss saprolites in the state of Pernambuco, Brazil (Santos et al., 2018b). Some grains seemed intensely dissolved, as inferred by the lack of sharp edges, when comparing the RMcontrol with the RM-woods after 378 days of being buried (Figure $2 \mathrm{~B}$ and $\mathrm{E}$ ). However, at this point, it was not possible to conclude that such morphology is the result of weathering into the soil only. Krahl et al. (2020) cultivated corn seedlings in pure basalt during 315 days and did not report any changes in rock grain morphology; however, the $\mathrm{pH}$ of the pots in their experiment was close to 9 , while that of the soil used in the present study was between 4 and 5 .

Changes in the intensity of diffracted X-rays are influenced by several factors (Moore \& Reynolds, 1997), including the amount of the diffracting phase in the sample. The changes in the relative XRD intensities of plagioclases $(0.425,0.344$, and $0.321 \mathrm{~nm}$ peaks) and pyroxenes $(0.299,0.294,0.289$, and $0.257 \mathrm{~nm}$ peaks) suggest that these are the most weathered phases in the coarse and fine sand fractions, when compared with the RM-control of each fraction (Figures 3, 4, and 5). Krahl et al. (2020) also noted that diopside (pyroxene) and andesine (plagioclase) samples were

Pesq. agropec. bras., Brasília, v.56, e01442, 2021

DOI: 10.1590/S1678-3921.pab2021.v56.01442 

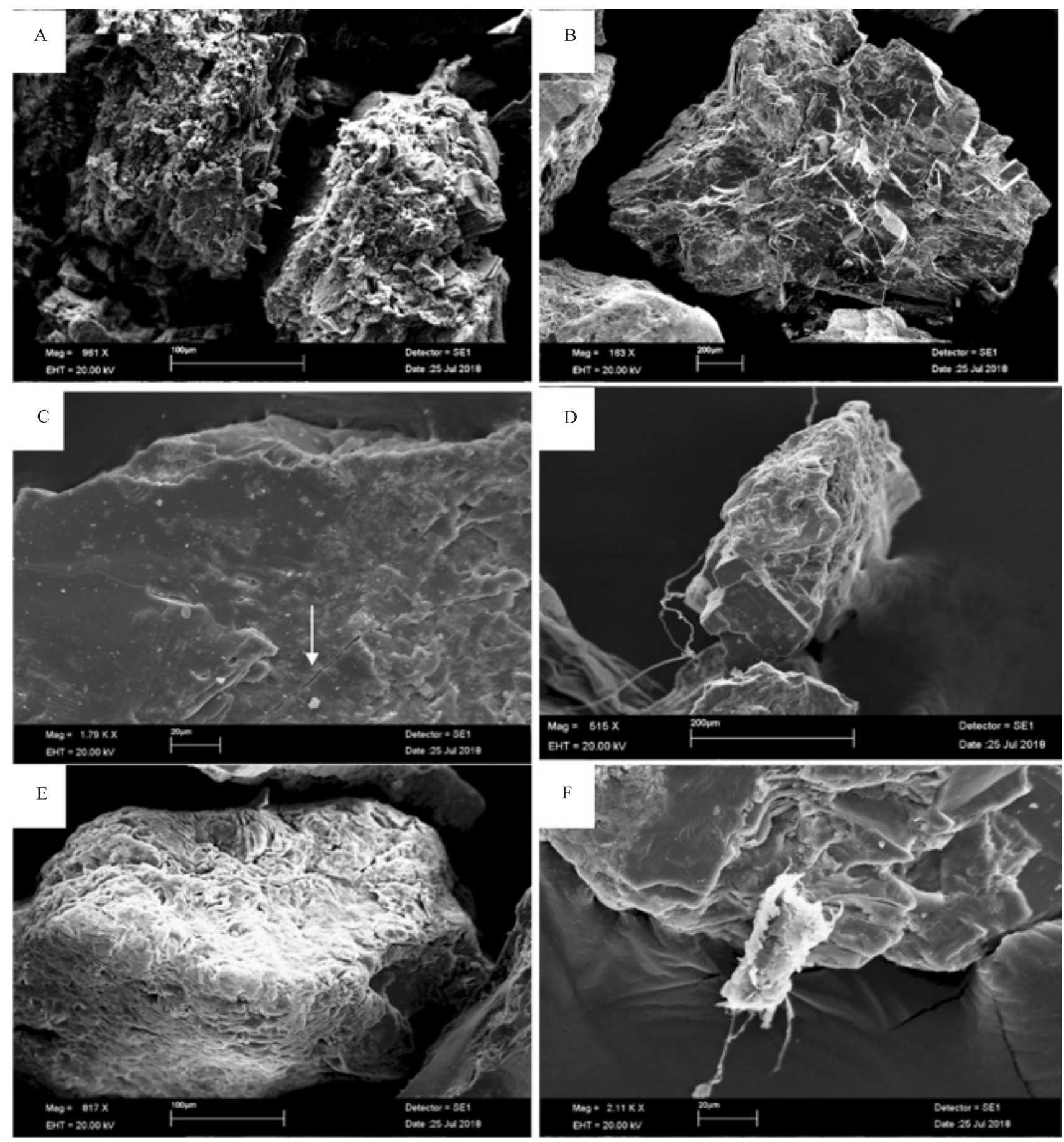

Figure 2. Scanning electron microscopy images of remineralizer (RM) grains, showing: A and B, fine and coarse sand fraction of the grains of the RM used as a control (RM-control), respectively; C, etched pits and a crack probably caused by mechanical stress during comminution (arrow) in the coarse sand fraction of the RM after being buried for 154 days in soil cultivated with corn (Zea mays); D, cleavage surfaces (possibly of a feldspar) and biological filament entangled to it in the fine sand fraction in the RM after being buried for 378 days in soil with elephant grass (Pennisetum purpureum); E, rounded surfaces, possibly due to preferential edge dissolution in the fine sand fraction in the RM after being buried for 378 days in soil in the woods, contrasting with the coarse sand fraction of the RM-control; and F, biological structure (possibly biofilm) at the edge of the grain, whose corrosion seems more intense around the biological structure in the coarse sand fraction in the RM after being buried for 378 days in the woods. 


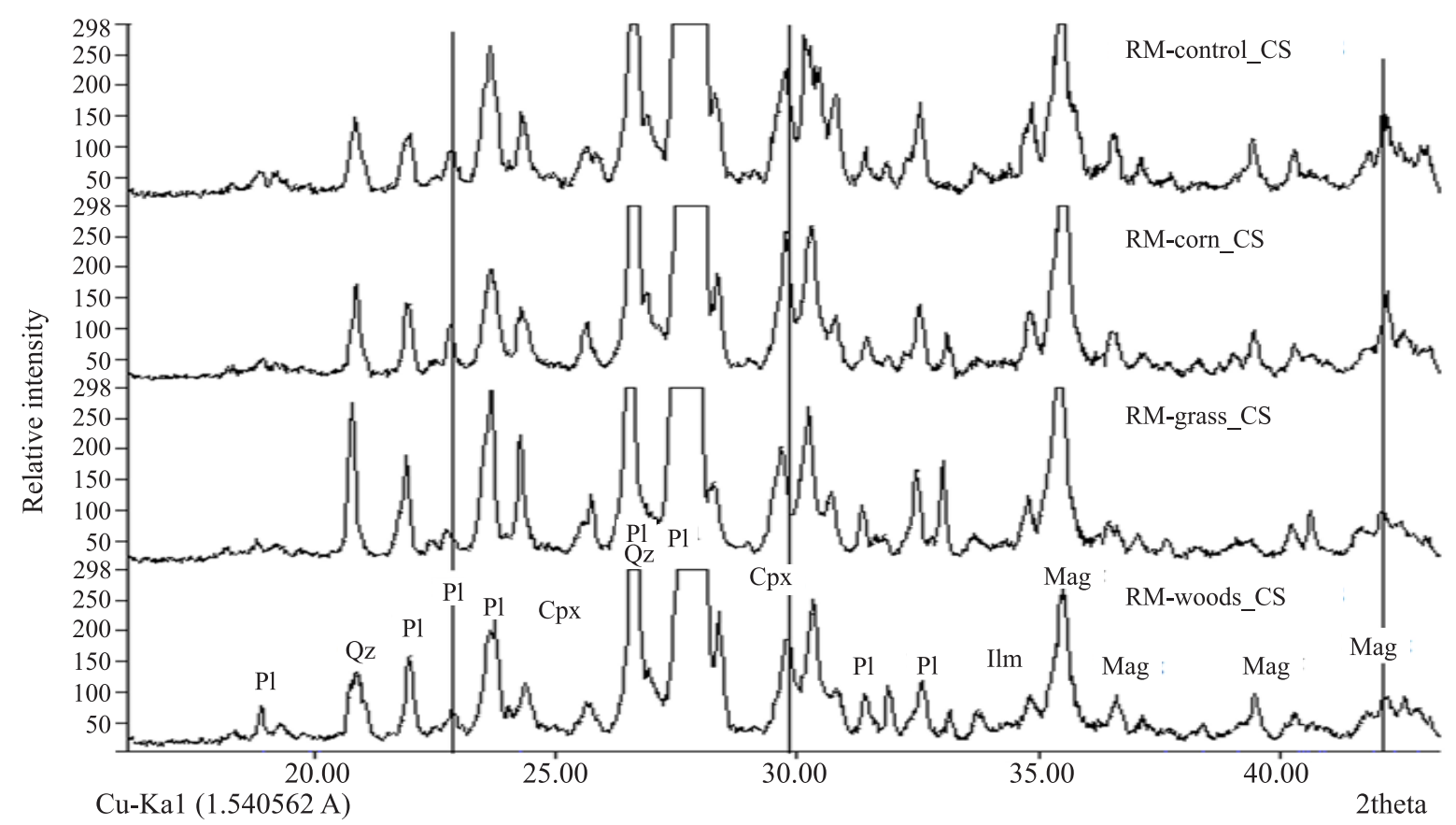

Figure 3. X-ray diffraction scans of the coarse sand fraction (CS) of the remineralizer used as a control (RM-control), after being buried for 154 days in soil cultivated with corn (Zea mays) (RM-corn) and for 378 days in soil under elephant grass (Pennisetum purpureum) (RM-grass) and woods (RM-woods). Pl, plagioclase; Qz, quartz; Cpx, clinopyroxenes; Ilm, ilmenite; and Mag, magnetite.

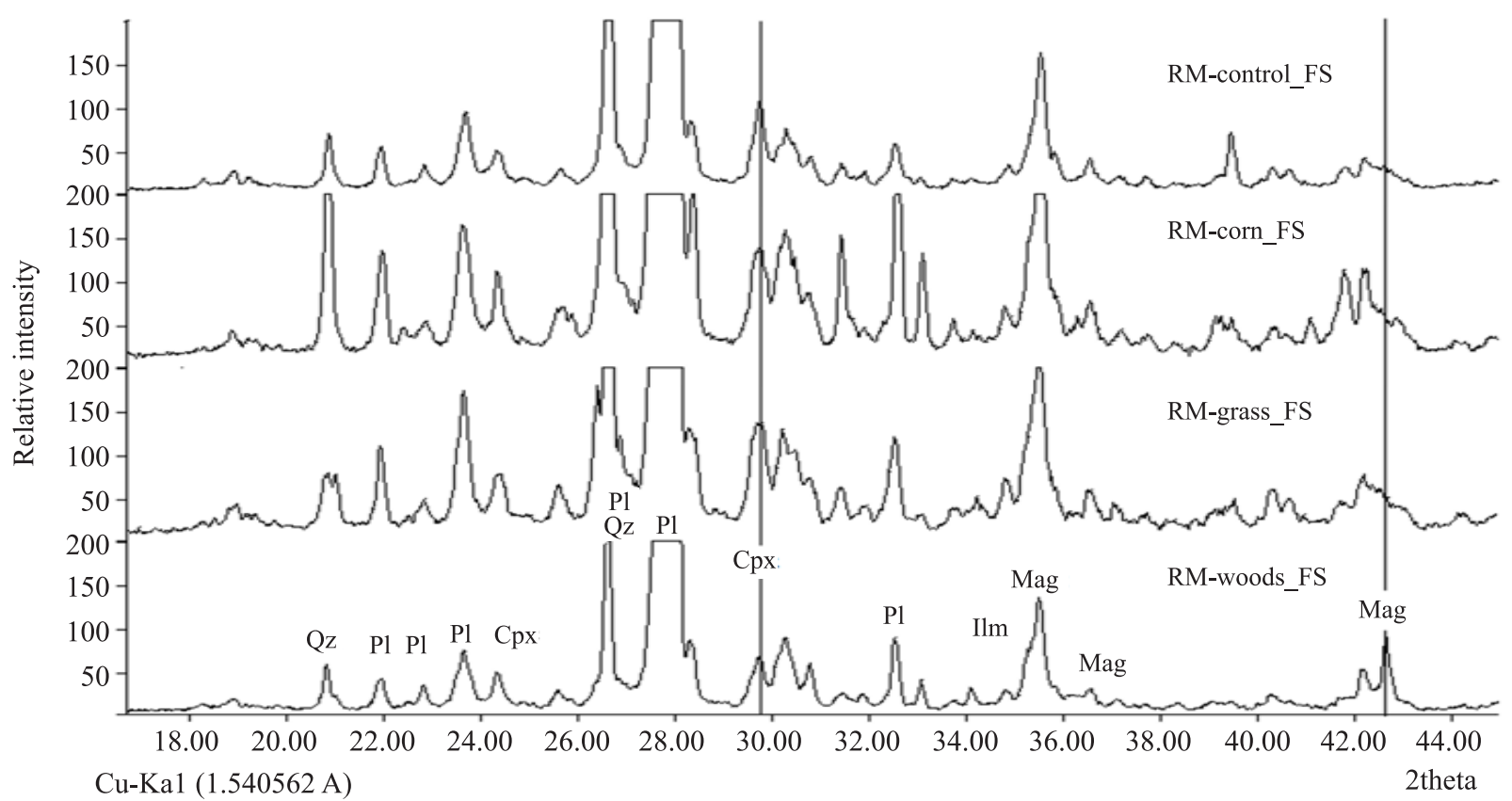

Figure 4. X-ray diffraction scans of the fine sand fraction (FS) of the remineralizer used as a control (RM-control), after being buried for 154 days in soil cultivated with corn (Zea mays) (RM-corn) and for 378 days in soil under elephant grass (Pennisetum purpureum) (RM-grass) and woods (RM-woods). Qz, quartz; Pl, plagioclase; Cpx, clinopyroxenes; Ilm, ilmenite; and Mag, magnetite. 
the most affected by dissolution in the analyzed samples. Besides the decrease observed for the relative intensities, an increase in peak width (full width at half maximum) and asymmetry seemed to have occurred, suggesting the advancement of weathering and the loss of crystallinity (Figures 3, 4, and 5), which is in agreement with the losses in elemental mass balance (Figure 6). Of the found minerals, the most dissolved were $\mathrm{Mg}$ and $\mathrm{Na}$, since pyroxenes and plagioclase feldspars were the source of $\mathrm{Mg}$ and $\mathrm{Na}$, respectively, and the elemental mass balance showed that the loss of $\mathrm{Mg}$ and $\mathrm{Na}$ was the greatest in all land uses, which roughly agrees with the changes observed in the XRD scan. It is interesting, though, that all land uses had the same pattern and magnitude of gains and losses of elements.

The amount of iron determined in the dithionitecitrate-bicarbonate and oxalate ammonium acid solutions $\left(\mathrm{Fe}_{\mathrm{d}}\right.$ and $\mathrm{Fe}_{\mathrm{o}}$, respectively) that was extracted from the RMs in the bags was from 9.5 to 13.3 and from 15.9 to 26.1 times greater, respectively, than that in the RM-control (Table 2). Even if some soil particles may have entered the bag, the amount of $\mathrm{Fe}_{\mathrm{d}}$ and $\mathrm{Fe}_{\mathrm{o}}$, respectively, was roughly 2 to 3 and about 40 times greater in the RM bags (that is, in RM-corn, RMgrass, and RM-woods) than in the surrounding soil. This suggests contamination should not have been a major process to increase $\mathrm{Fe}_{\mathrm{d}}$ and $\mathrm{Fe}_{\mathrm{o}}$ in the bags. Interestingly, Krahl et al. (2020) found precipitates they supposed were amorphous phases on the surface of the studied grains due to the rapid oxidation of Fe(II). Despite the great increase observed for $\mathrm{Fe}_{\mathrm{d}}$ and $\mathrm{Fe}_{\mathrm{o}}$, their values were mostly erratic along the timeline. For $\mathrm{RM}$-grass and $\mathrm{RM}$-woods, the greatest $\mathrm{Fe}_{\mathrm{o}}$ value was verified in the first unburied bag at 86 days, suggesting that the Fe release was fast and occurred in the first three months. In fact, the incongruent dissolution of silicates results in a great mass of chemical elements released at the beginning of dissolution, followed by a smaller, roughly constant rate of release (Wild

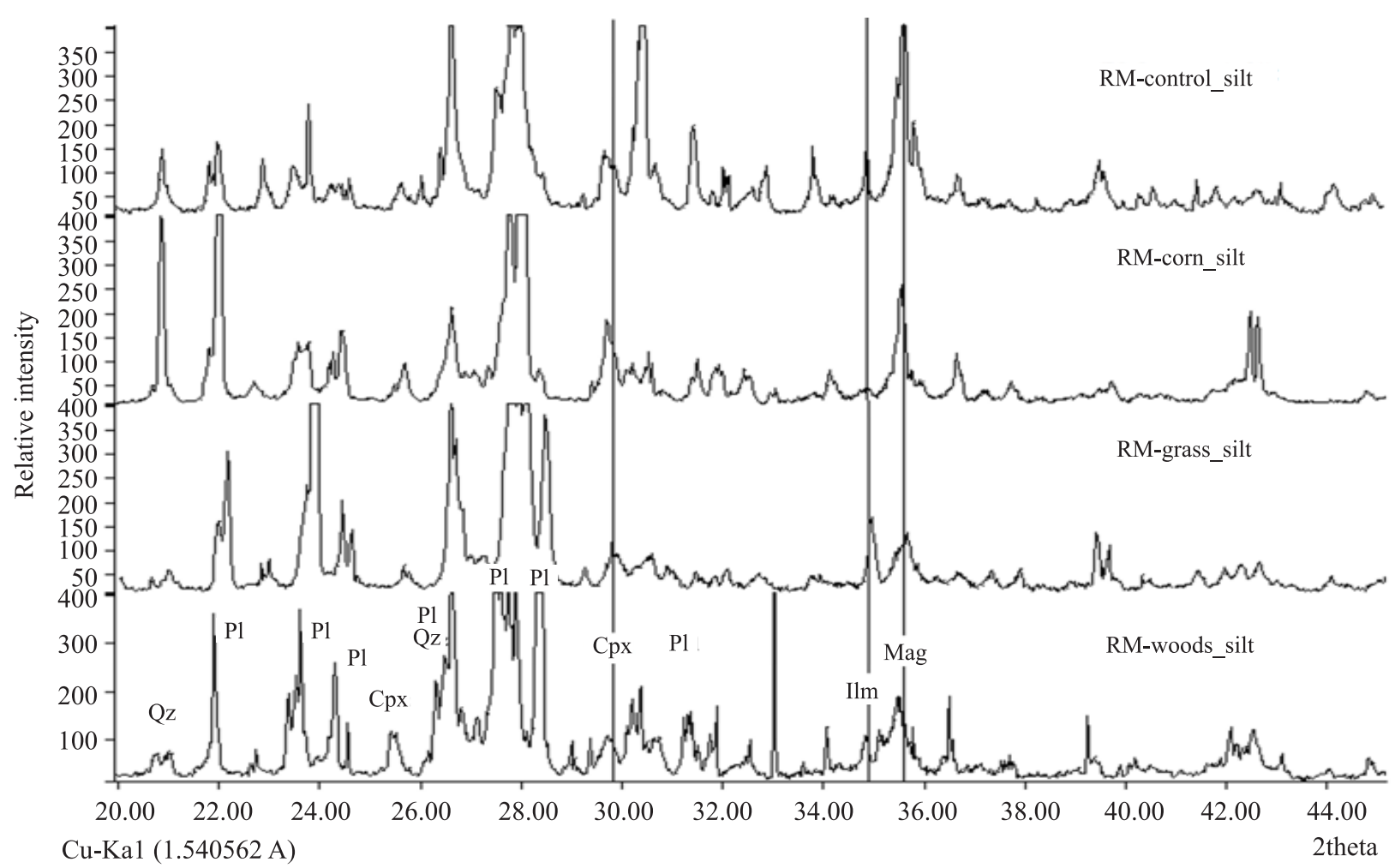

Figure 5. X-ray diffraction scans of the silt fraction of the remineralizer used as a control (RM-control), after being buried for 154 days in soil cultivated with corn (Zea mays) (RM-corn) and for 378 days in soil under elephant grass (Pennisetum purpureum) (RM-grass) and woods (RM-woods). Qz, quartz; Pl, plagioclase; Cpx, clinopyroxenes; Ilm, ilmenite; and Mag, magnetite. 
et al., 2016). It was surprising, though, that, in open system conditions, the dissolution peak occurred in less than three months. The sources of Fe in the RM were the Fe-Mg silicates, mainly pyroxenes, which dissolve incongruently, and primary Fe-oxides, such as magnetite and ilmenite, which dissolve congruently (Crundwell, 2015).

The values of $\mathrm{Al}$ determined in the dithionitecitrate-bicarbonate solution $\left(\mathrm{Al}_{\mathrm{d}}\right)$ were also erratic, varying from 1.9 to 2.8 times the content in the RMcontrol, with no apparent relationship with $\mathrm{Fe}_{\mathrm{d}}$. This could be attributed to the fact that the source of $A l_{d}$ is mainly the $\mathrm{Al}$ in isomorphic substitution in the atomic structure of reducible metal oxides, such as Fe and $\mathrm{Mn}$ oxides; the total $\mathrm{Fe}_{2} \mathrm{O}_{3}$ and $\mathrm{MnO}$ in the RM-control was 14.4 and $0.24 \%$, respectively. The most impressive increase in the ratio between the RM-bags and RMcontrol was found for $\mathrm{Al}$ determined in oxalate ammonium acid solution $\left(\mathrm{Al}_{\mathrm{o}}\right)$, which was 120 to 175 times greater, indicating an extensive transformation in the $\mathrm{Al}$ forms. However, the elemental mass balance for $\mathrm{Al}_{2} \mathrm{O}_{3}$ was about zero (Figure 6). Together, the elemental mass balance and the $\mathrm{Al}_{\mathrm{d}}$ and $\mathrm{Al}_{\mathrm{o}} \mathrm{RM}-\mathrm{bag} /$ $\mathrm{RM}$-control ratios suggest that, despite the loss of $\mathrm{Al}_{2} \mathrm{O}_{3}$ being in the same order of the overall mass loss of the RM, the $\mathrm{Al}$ atoms had a massive transfer from

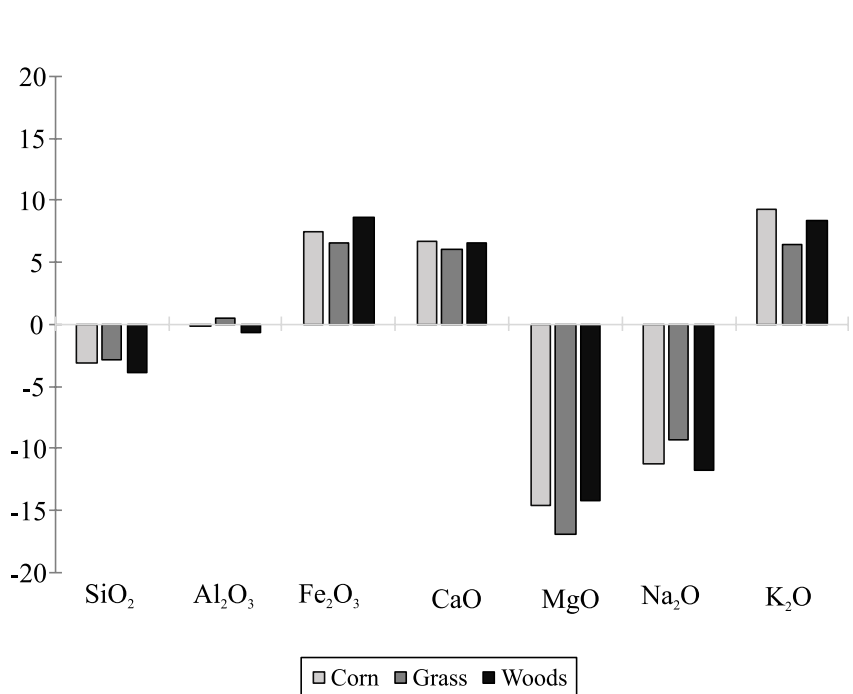

Figure 6. Elemental mass balance based on the total chemical analysis of the remineralizer (RM) samples unburied after 154 days in soil cultivated with corn (Zea mays) and after 378 days in soils under elephant grass (Pennisetum purpureum) and woods, in comparison with the pristine RM (control). crystalline and lithogenic minerals to amorphous ones. This could be attributed to the fact that the elemental mass balance accounts only for the mass of elements that leaves the "volume of control" of the system, i.e., the volume of the bags. Therefore, the obtained result is indicative of the loss of elements, as observed for $\mathrm{MgO}$ and $\mathrm{Na}_{2} \mathrm{O}$, or of their residual concentration, as for $\mathrm{Fe}_{2} \mathrm{O}_{3}$ and $\mathrm{CaO}$, but does not inform about their phase transformations in situ - from the crystalline to the amorphous phase, for example. The large increase in $\mathrm{Al}_{\mathrm{o}}$ is certainly related to plagioclase weathering, the main and abundant source of $\mathrm{Al}$ in the RM, with $11.90 \%$ total $\mathrm{Al}_{2} \mathrm{O}_{3}$ in the $\mathrm{RM}$-control. Plagioclase was also the source of $\mathrm{Na}$ and $\mathrm{Ca}$, with $3.06 \%$ total $\mathrm{Na}_{2} \mathrm{O}$

Table 2. Iron and aluminum contents extracted with dithionite citrate bicarbonate $\left(\mathrm{Fe}_{\mathrm{d}}\right.$ and $\left.\mathrm{Al}_{\mathrm{d}}\right)$ and ammonium oxalate $\left(\mathrm{Fe}_{\mathrm{o}}\right.$ and $\left.\mathrm{Al}_{\mathrm{o}}\right)$ solutions that were found in the remineralizers both in pristine conditions (RM-control) and after being buried in soil under different land uses ${ }^{(1)}$ and for different periods (number of days).

\begin{tabular}{|c|c|c|c|c|c|c|}
\hline Days $^{(2)}$ & $\mathrm{Fe}_{\mathrm{d}}$ & $\mathrm{Fe}_{\mathrm{o}}$ & $\mathrm{Al}_{\mathrm{d}}$ & $\mathrm{Al}_{\circ}$ & $\mathrm{Fe}_{\mathrm{o}} / \mathrm{Fe}_{\mathrm{d}}$ & $\mathrm{Al}_{\mathrm{o}} / \mathrm{Al}_{\mathrm{d}}$ \\
\hline \multirow[t]{2}{*}{ RM-control } & 3.51 & 1.04 & 1.59 & 0.02 & 0.3 & 0.01 \\
\hline & \multicolumn{6}{|c|}{ RM-corn } \\
\hline 59 & 38.7 & 20.4 & 3.5 & 2.9 & 0.5 & 0.8 \\
\hline 86 & 41.7 & 21.7 & 3.1 & 3.0 & 0.5 & 1.0 \\
\hline 119 & 46.7 & 20.0 & 4.3 & 2.8 & 0.4 & 0.7 \\
\hline \multirow[t]{2}{*}{154} & 46.1 & 22.5 & 3.2 & 3.2 & 0.5 & 1.0 \\
\hline & \multicolumn{6}{|c|}{ RM-grass } \\
\hline 86 & 40.5 & 22.0 & 3.7 & 3.2 & 0.5 & 0.9 \\
\hline 182 & 33.5 & 16.6 & 4.4 & 2.4 & 0.5 & 0.5 \\
\hline 274 & 38.5 & 20.5 & 4.0 & 3.0 & 0.5 & 0.8 \\
\hline \multirow[t]{2}{*}{378} & 38.4 & 18.3 & 4.2 & 2.6 & 0.5 & 0.6 \\
\hline & \multicolumn{6}{|c|}{ RM-woods } \\
\hline 86 & 33.2 & 27.2 & 4.1 & 3.5 & 0.8 & 0.9 \\
\hline 182 & 35.3 & 25.4 & 3.3 & 3.1 & 0.7 & 0.9 \\
\hline 274 & 33.9 & 22.2 & 3.1 & 2.9 & 0.7 & 0.9 \\
\hline 378 & 41.0 & 22.6 & 3.8 & 3.2 & 0.6 & 0.9 \\
\hline
\end{tabular}

${ }^{(1)} \mathrm{RM}$-corn, corn (Zea mays) crop; RM-grass, elephant grass (Pennisetum purpureum); and RM-woods, forest fragment. ${ }^{(2)}$ Days counted from the burial of the bags in January 30, 2014. 
and $6.94 \%$ total $\mathrm{CaO}$ in the $\mathrm{RM}$-control, respectively. The loss of $\mathrm{Na}$ contrasts with the residual increase in $\mathrm{Ca}$ can be explained both by the greater mobility of $\mathrm{Na}$ (Hudson, 1995) and the albitic (Na-rich) composition of the borders of the plagioclase grains that should weather before their more anorthitic (Ca-rich) core that should weather later. In addition to these processes, the mineralization of carbon or mineral carbonation which causes the carbon in atmospheric $\mathrm{CO}_{2}$ to react with alkaline earth metals (usually $\mathrm{Ca}$ ) and precipitate $\mathrm{CaCO}_{3}$ (Moosdorf et al., 2014; Kantola et al., 2017; Taylor et al., 2017; Beerling et al., 2018) - may have occurred inside the bags, since it was observed at a much lower RM concentration in the soil (Manning, 2008; Manning et al., 2013; Washbourne et al., 2015). If this process happened inside the bags, some amount of $\mathrm{Ca}$ would accumulate as $\mathrm{CaCO}_{3}$.

In summary, the results of the elemental mass balance calculated in the present study with a very simple approach agreed roughly with those of the XRD scans. The great loss in $\mathrm{MgO}$ and $\mathrm{Na}_{2} \mathrm{O}$ fits well with the expectation that $\mathrm{Fe}-\mathrm{Mg}$ silicates (mainly pyroxenes) and plagioclases should weather first. Potassium was enriched into the bags because it should be present in the K-feldspars, which are more resistant to weathering than the plagioclases (Ca-feldspars) (Bakker et al., 2019). $\mathrm{Fe}_{2} \mathrm{O}_{3}$ accumulated residually, but, as shown by the results for $\mathrm{DCB}$ and $\mathrm{AAO}$, has gone through a great transfer from the lithogenic to the pedogenic and amorphous forms. Aluminum went through a similar transformation from primary minerals to amorphous ones, which was up to 175 times greater for $\mathrm{Al}_{\mathrm{o}}$ in the RM-bags than in the RM-control (Table 2), possibly explaining why its loss was comparatively greater than that of $\mathrm{Fe}_{2} \mathrm{O}_{3}$ (Figure 6). Silicon, the most abundant element in the $\mathrm{RM}\left(52.10 \% \mathrm{SiO}_{2}\right.$ in the RMcontrol) should also have gone through extensive transformations since $\mathrm{Si}$ is a major element in the composition of silicates, pyroxenes, and plagioclases that have undergone extensive weathering (Stefánsson, 2001); however, its loss was not significant in the mass balance because its mobility is intermediary (Hudson, 1995) and it forms amorphous silica layers on the mineral's surface (Daval et al., 2011, 2018; Hellmann et al., 2013).

These findings are interesting because they serve as a reference (including some order of magnitude) to infer mechanisms of diabase dissolution and to elaborate hypotheses to test the role of RMs applied to the soil beyond the regular release of plant nutrients and potentially toxic elements. Further research could be carried out on the potential to capture atmospheric carbon, the protection of organic matter by the formation of organic-mineral complexes between organic substances and recently precipitated amorphous metal oxides, the impact of recently precipitated amorphous metals in the "fixation" of phosphate applied to agricultural soils, and the role of soil microbiomes and the rhizosphere in the dissolution rate of RMs, among others.

\section{Conclusions}

1. Plagioclases and pyroxenes are the most weathered minerals found in the diabase remineralizer (RM) buried in bags into the soil.

2. The three land uses evaluated show the same pattern of gain and losses of elements.

3. The ratios iron determined in oxalate ammonium acid solution $\left(\mathrm{Fe}_{\mathrm{o}}\right)$ in the RM-bags/ $\mathrm{Fe}_{\mathrm{o}}$ in the RMcontrol and aluminum determined in oxalate ammonium acid solution $\left(\mathrm{Al}_{\mathrm{o}}\right)$ in the $\mathrm{RM}-\mathrm{bags} / \mathrm{Al}_{\mathrm{o}}$ in the RM-control express a massive transfer of these elements from the crystalline and lithogenic to the pedogenic and amorphous phase, with values from 16 to 26 and 120 to 175 , respectively, but a small mobility of aluminum.

\section{Acknowledgments}

To Coordenação de Aperfeiçoamento de Pessoal de Nível Superior (Capes), for for financing, in part, this study (Finance Code 001), through a grant to the first author; to Conselho Nacional de Desenvolvimento Científico e Tecnológico (CNPq), for financial support (process number 406600/2013-9) and grants (process numbers 305725/2012-2 and 304660/2016-7); and to the Godoy family, owners of the Paineira Branca farm, for the partnership in this research.

\section{References}

ALVARES, C.A.; STAPE, J.L.; SENTELHAS, P.C.; GONÇALVES, J.L. de M.; PAROVEK, G. Köppen's climate classification map for Brazil. Meteorologische Zeitschrift, v.22, p.711-728, 2013. DOI: https://doi.org/10.1127/09412948/2013/0507. 
ANDA, M.; SHAMSHUDDIN, J.; FAUZIAH, C.I. Improving chemical properties of a highly weathered soil using finely ground basalt rocks. Catena, v.124, p.147-161, 2015. https://doi.org/10.1016/j.catena.2014.09.012.

BAKKER, E.; LANSON, B.; FINDLING, N.; WANDER, M.M.; HUBERT, F. Mineralogical differences in a temperate cultivated soil arising from different agronomic processes and plant K-uptake. Geoderma, v.347, p.210-219, 2019. https://doi.org/10.1016/J.GEODERMA.2019.04.010.

BEERLING, D.J.; LEAKE, J.R.; LONG, S.P.; SCHOLES, J.D.; TON, J.; NELSON, P.N.; BIRD, M.; KANTZAS, E.; TAYLOR, L.L.; SARKAR, B.; KELLAND, M.; DELUCIA, E.; KANTOLA, I.; MÜLLER, C.; RAU, G.H.; HANSEN, J. Farming with crops and rocks to address global climate, food and soil security. Nature Plants, v.4, p.138-147, 2018. https://doi.org/10.1038/s41477-0180108-y.

BENEDETTI, M.F.; MENARD, O.; NOACK, Y.; CARVALHO, A.; NAHON, D. Water-rock interactions in tropical catchments: field rates of weathering and biomass impact. Chemical Geology, v.118, p.203-220, 1994. DOI: https://doi.org/10.1016/00092541(94)90177-5.

CRUNDWELL, F.K. The mechanism of dissolution of the feldspars: Part I. Dissolution at conditions far from equilibrium. Hydrometallurgy, v.151, p.151-162, 2015. DOI: https://doi.org/10.1016/j.hydromet.2014.10.006.

DAVAL, D.; CALVARUSO, C.; GUYOT, F.; TURPAULT, M.-P. Time-dependent feldspar dissolution rates resulting from surface passivation: experimental evidence and geochemical implications. Earth and Planetary Science Letters, v.498, p.226-236, 2018. DOI: https://doi.org/10.1016/j.epsl.2018.06.035.

DAVAL, D.; SISSMANN, O.; MENGUY, N.; SALDI, G.D.; GUYOT, F.; MARTINEZ, I.; CORVISIER, J.; GARCIA, B.; MACHOUK, I.; KNAUSS, K.G.; HELLMANN, R. Influence of amorphous silica layer formation on the dissolution rate of olivine at $90^{\circ} \mathrm{C}$ and elevated pCO2. Chemical Geology, v.284, p.193-209, 2011. https://doi.org/10.1016/j.chemgeo.2011.02.021.

FARIA, C.A. Evolução magmática do Sill de Limeira: petrografia e geoquímica. 2008. 106p. Dissertação (Mestrado) Universidade de São Paulo, São Paulo.

GANOR, J.; LU, P.; ZHENG, Z.; ZHU, C. Bridging the gap between laboratory measurements and field estimations of silicate weathering using simple calculations. Environmental Geology, v.53, p.599-610, 2007. DOI: https://doi.org/10.1007/s00254-0070675-0.

GARRELS, R.M.; CHRIST, C.L. Solutions, minerals and equilibria. New York: Harper \& Row, 1965.

GILL, R. Rochas e processos ígneos: um guia prático. Porto Alegre: Bookman, 2014. 427p.

HARLEY, A.D.; GILKES, R.J. Factors influencing the release of plant nutrient elements from silicate rock powders: a geochemical overview. Nutrient Cycling in Agroecosystems, v.56, p.11-36, 2000. DOI: https://doi.org/10.1023/A:1009859309453.

HEINDEL, R.C.; LYONS, W.B; WELCH, S.A.; SPICKARD, A.M.; VIRGINIA, R.A. Biogeochemical weathering of soil apatite grains in the McMurdo Dry Valleys, Antarctica. Geoderma, v.320, p.136-145, 2018. DOI: https://doi.org/10.1016/j. geoderma.2018.01.027.

HELLMANN, R.; DAVAL, D.; WIRTH, R. Formation of amorphous silica surface layers by dissolution-reprecipitaton during chemical weathering: implications for CO2 uptake. Procedia Earth and Planetary Science, v.7, p.346-349, 2013. DOI: https://doi.org/10.1016/j.proeps.2013.03.154.

HUDSON, B.D. Reassessment of Polynov's ion mobility series. Soil Science Society of America Journal, v.59, p.1101-1103, 1995. DOI: https://doi.org/10.2136/sssaj1995.03615995005900040022x.

KANTOLA, I.B.; MASTERS, M.D.; BEERLING, D.J.; LONG, S.P.; DELUCIA, E.H. Potential of global croplands and bioenergy crops for climate change mitigation through deployment for enhanced weathering. Biology Letters, v.13, 20160714, 2017. DOI: https://doi.org/10.1098/rsbl.2016.0714.

KRAHL, L.L.; PAZ, S.P.A. da; ANGELICA, R.S.; VALADARES, L.F.; SOUSA-SILVA, J.C.; MARCHI, G.; MARTINS, É. de S. Successive off take of elements by maize grown in pure basalt powder. African Journal of Agricultural Research, v.15, p.229239, 2020. DOI: https://doi.org/10.5897/AJAR2019.14546.

LEONARDOS, O.H.; THEODORO, S.H.; ASSAD, M.L. Remineralization for sustainable agriculture: a tropical perspective from a Brazilian viewpoint. Nutrient Cycling in Agroecosystems, v.56, p.3-9, 2000. DOI: https://doi.org/10.1023/A:1009855409700.

MANNING, D.A.C. Biological enhancement of soil carbonate precipitation: passive removal of atmospheric $\mathrm{CO}_{2}$. Mineralogical Magazine, v.72, p.639-649, 2008. DOI: https://doi.org/10.1180/ minmag.2008.072.2.639.

MANNING, D.A.C. Mineral sources of potassium for plant nutrition. A review. Agronomy for Sustainable Development, v.30, p.281-294, 2010. DOI: https://doi.org/10.1051/agro/2009023.

MANNING, D.A.C.; RENFORTH, P.; LOPEZ-CAPEL, E.; ROBERTSON, S.; GHAZIREH, N. Carbonate precipitation in artificial soils produced from basaltic quarry fines and composts: an opportunity for passive carbon sequestration. International Journal of Greenhouse Gas Control, v.17, p.309-317, 2013. DOI: https://doi.org/10.1016/j.ijggc.2013.05.012.

MCKEAGUE, J.A. Manual on soil sampling and methods of analysis. $2^{\text {nd }}$ ed. Ottawa: Canadian Society of Soil Science, 1978. 212 p.

MEHRA, O.P.; JACKSON, M.L. Iron oxide removal from soils and clays by a dithionite-citrate system buffered with sodium bicarbonate. Clays and Clay Minerals, v.7, p.317-327, 1958. DOI: https://doi.org/10.1016/B978-0-08-009235-5.50026-7.

MOORE, D.M.; REYNOLDS, R.C. X-ray diffraction and the identification and analysis of clay minerals. Oxford: Oxford University Press, 1997.

MOOSDORF, N.; RENFORTH, P.; HARTMANN, J. Carbon dioxide efficiency of terrestrial enhanced weathering. Environmental Science \& Technology, v.48, p.4809-4816, 2014. DOI: https://doi.org/10.1021/es4052022.

PALANDRI, J.L.; KHARAKA, Y.K. A compilation of rate parameters of water-mineral interaction kinetics for 
application to geochemical modeling. Menlo Park: U.S. Geological Survey, 2004. Open File Report 2004-1068. DOI: https://doi.org/10.3133/ofr20041068.

RAIJ, B. VAN; ANDRADE, J.C. de; CANTARELLA, H.; QUAGGIO, J.A. (Ed.). Análise química para avaliação da fertilidade de solos tropicais. Campinas: IAC, 2001. 285p.

RAMOS, C.G.; QUEROL, X.; OLIVEIRA, M.L.S.; PIRES, K.; KAUTZMANN, R.M.; OLIVEIRA, L.F.S. A preliminary evaluation of volcanic rock powder for application in agriculture as soil a remineralizer. Science of the Total Environment, v.512-513, p.371-380, 2015. DOI: https://doi.org/10.1016/j. scitotenv.2014.12.070.

SANTOS, H.G. dos; JACOMINE, P.K.T.; ANJOS, L.H.C. dos; OLIVEIRA, V.Á. de; LUMBRERAS, J.F.; COELHO, M.R.; ALMEIDA, J.A. de; ARAÚJO FILHO, J.C. de; OLIVEIRA, J.B. de; CUNHA, T.J.F. Sistema brasileiro de classificação de solos. 5.ed. rev. e ampl. Brasília: Embrapa, 2018a. 356p.

SANTOS, J.C.B. dos; LE PERA, E.; SOUZA JÚNIOR, V.S. de; OLIVEIRA, C.S. de; JUILlERET, J.; CORRÊA, M.M.; AZEVEDO, A.C. de. Porosity and genesis of clay in gneiss saprolites: the relevance of saprolithology to whole regolith pedology. Geoderma, v.319, p.1-13, 2018b. DOI: https://doi.org/10.1016/j.geoderma.2017.12.031.

SILVA, R.C. da; CURY, M.E.; IEDA, J.J.C.; SERMARINI, R.A.; AZEVEDO, A.C. de; Chemical attributes of a remineralized Oxisol. Ciência Rural, v.47, e20160982, 2017. DOI: https://doi.org/10.1590/0103-8478cr20160982.

SOIL SURVEY STAFF. Keys to soil taxonomy. $12^{\text {th }}$ ed. Washington: USDA, 2014. 360p.

STEFÁNSSON, A. Dissolution of primary minerals of basalt in natural waters: I. Calculation of mineral solubilities from $0^{\circ} \mathrm{C}$ to $350^{\circ} \mathrm{C}$. Chemical Geology, v.172, p.225-250, 2001. DOI: https://doi.org/10.1016/S0009-2541(00)00263-1.
TAYLOR, L.L.; BEERLING, D.J.; QUEGAN, S.; BANWART, S.A. Simulating carbon capture by enhanced weathering with croplands: an overview of key processes highlighting areas of future model development. Biology Letters, v.13, 20160868, 2017. DOI: https://doi.org/10.1098/rsbl.2016.0868.

VAN STRAATEN, P. Farming with rocks and minerals: challenges and opportunities. Anais da Academia Brasileira de Ciências, v.78, p.731-747, 2006. DOI: https://doi.org/10.1590/ S0001-37652006000400009.

WASHBOURNE， C.-L.; LOPEZ-CAPEL， E.; RENFORTH, P.; ASCOUGH, P.L.; MANNING, D.A.C. Rapid removal of atmospheric $\mathrm{CO}_{2}$ by urban soils. Environmental Science \& Technology, v.49, p.5434-5440, 2015. DOI: https://doi.org/10.1021/ es505476d.

WHITE, A.F.; BRANTLEY, S.L. The effect of time on the weathering of silicate minerals: why do weathering rates differ in the laboratory and field? Chemical Geology, v.202, p.479-506, 2003. DOI: https://doi.org/10.1016/j.chemgeo.2003.03.001.

WHITE, G.N.; FELDMAN, S.B.; ZELAZNY, L.W. Rates of nutrient release by mineral weathering. In: LUCIER, A.A.; HAINES, S.G. (Ed.). Mechanisms of forest response to acidic deposition. New York: Springer, 1990. p.108-162. DOI: https://doi.org/10.1007/978-1-4612-3364-0_4.

WILD, B.; DAVAL, D.; GUYOT, F.; KNAUSS, K.G.; POLLETVILLARD, M.; IMFELD, G. pH-dependent control of feldspar dissolution rate by altered surface layers. Chemical Geology, v.442, p.148-159, 2016. DOI: https://doi.org/10.1016/j. chemgeo.2016.08.035.

YOKOYAMA, T.; MATSUKURA, Y. Field and laboratory experiments on weathering rates of granodiorite: separation of chemical and physical processes. Geology, v.34, p.809-812, 2006. DOI: https://doi.org/10.1130/G22625.1. 